\title{
Marital readiness: Exploring the key factors among university students
}

\author{
Danik Nur Fitria Ningrum, Melly Latifah, Diah Krisnatuti \\ Department of Family and Consumer Sciences, IPB University, Indonesia \\ Corresponding Author: danik.fitria297@gmail.com
}

\section{ARTICLE INFO}

Article history

Received September 7, 2020

Revised January 6, 2021

Accepted February 26, 2021

\section{Keywords}

emotional intelligence;

family life preparation;

family life knowledge;

marital readiness;

university student

\begin{abstract}
Marital readiness, particularly in young adults, is an important aspect that will determine success in building a relationship with their spouse in the future. This study aimed to explore the key factors affecting marital readiness among university students. Critical factors included in this study design are age, family life preparation programs, emotional intelligence, and family life knowledge. A quantitative explanatory study with 120 university students in Jakarta Province as participants was conducted. Questionnaires consist of demographic data, family life knowledge, emotional intelligence, and marital readiness were used to collect the data. The data were then analyzed using PLS-SEM to determine the effect of the key factors on marital readiness. The results show that marital readiness is significantly influenced by age, involvement in family life preparation programs, family life knowledge, and emotional intelligence. Therefore, participating in family life preparation programs will enhance knowledge about preparing for family life, which will then increase marital readiness. Also, marital readiness will increase when university students have higher emotional intelligence and age.
\end{abstract}

\section{Introduction}

Arnett (2015) suggests that the age range of 18-25 years is transitioning from late adolescence to young adults' emergence. Like other stages of age, young adults also have demanding developmental tasks to complete. One goal is to build strong and lasting relationships with their partners through marriage (Papalia, Olds, \& Feldman, 2009). For this reason, young adults need to equip themselves with marital readiness. Marital readiness may improve the quality of a marriage. Holman \& Li (1997) stated that marital readiness is one of the essential factors determining marriage quality in the future.

Marital readiness is an important thing for every couple who is getting married to reduce the divorce rate. The trend of the divorce rate in Indonesia is increasing from year to year. The number of divorces in almost all provinces in Indonesia increased in the 2016-2019 period (Statistic Indonesia, 2020). DKI Jakarta Province is the fifthhighest number of divorces in Indonesia, with an average increase in divorces of more than 1,000 cases in a year. The divorced cases from 2016 to 2019 are 11,$321 ; 12,653$; 14,163 and 15,325, respectively. Of course, the high number of divorces is quite alarming, considering the impact of divorce can potentially reduce human resources' quality in the future.

Marital readiness is the ability perceived by individuals to carry out the roles, responsibilities, and challenges of marriage (Larson \& Thayne, 1999). However, readiness to marry is still not a priority for most families and couples getting married. 
The research's result of Willoughby, Olson, Carroll, Nelson, \& Miller (2012) shows only a few students consider preparation before marriage as necessary enough as a prerequisite for marriage. Also, not a few men and women are less aware of the need for mature readiness before heading to a marriage (Meiandayati, Nirmala, Didah, \& Susanti, 2015). Various research results show that the lack of readiness to marry has an impact on marital discord and disharmony, economic problems, one partner leaves obligations, does not work correctly, and the quality of child development is low (Sari, Khasanah, \& Sartika, 2016; Setiawati \& Marnelly, 2017; Sunarti, Simanjuntak, Rahmatin, \& Dianeswari, 2012; Tsania, Sunarti, \& Krisnatuti, 2015).

According to Carroll et al. (2009), age affects marriage readiness. The more mature the age at marriage, the better the readiness to marry (Larson \& LaMont, 2005; Sari \& Sunarti, 2013). Kuperberg (2014) stated marriage at an immature age are more likely to divorce because they are not ready to get married. Being in young adulthood is the best age to get married because teenage marriages are more prone to lead to divorce than marriage in adulthood (Santrock, 2014).

Family life knowledge is an understanding of reproductive health and rights as well as preparation for entering family life so that later marriages can be planned in full and according to the reproductive health cycle (Yatim, 2015). The results of Krisnatuti \& Oktaviani (2011) research indicate that a person will be better prepared to marry by having sufficient knowledge. Knowledge about family life becomes the capital in achieving intellectual readiness to enter married life. Knowledge and skills in the organization of family resources are needed to meet the family's information. High intellectual readiness is a family asset to get better resources (Sunart et al., 2012).

Knowledge and skills are needed in managing family resources to meet the information needed by the family. According to Murray \& Murray (2004), pre-marriage preparation counseling can be a resource for young adults to obtain various information and knowledge to improve the relationship's quality after marriage later. Several studies have shown that prenuptial preparation counseling programs in America and Iran are proven to increase partner satisfaction, knowledge, and married life skills (Farnam, Pakgohar, \& Mir-mohammadali, 2011; Fawcett, Hawkins, Blanchard, \& Carroll, 2010). Meanwhile, in Indonesia, through the National Population and Family Planning Board, the government has established a Student Information and Counseling Center (Pusat Informasi Konseling Mahasiswa or PIK-M) as a forum for the preparation of family life preparation program for students. The program aims to prepare students with various knowledge and skills as provisions for managing family life. The existence and role of PIK-M in the student environment are vital in helping students obtain relevant information and counseling services about preparing for family life. However, the extent to which family life preparation program (PIK-M) affects the readiness to marry among students has not been widely studied. In this study, it is assumed that students who participate in the family life preparation program (PIK-M) have the opportunity to know about careful planning for family life. If accompanied by high emotional intelligence, this knowledge can make students have to reach marital readiness.

Emotional intelligence has been identified as a success factor in marriage adjustment and satisfaction (Hajihasani \& Sim, 2018; Kalsoom \& Kamal, 2018; Abbasi, Tabatabaei, Sharbaf, \& Karshki, 2016). Emotional intelligence also affects an individual's readiness to marry. Emotional intelligence will determine a person's attitude towards himself (intrapersonal) such as self-awareness, self-motivation, self-regulation, and towards others (interpersonal) such as empathy, the ability to understand others and 
their social environment (Goleman, 1999). The results of Kurniawan (2019) research have shown that emotional intelligence determines a person's decision to marry.

Given the importance of preparing well before marriage for individuals entering reproductive age, research on marriage readiness is very important. Several previous researchers have reviewed research related to marital readiness in young adults. Previous research has focused on marital readiness in young adults and its relation with marriage age and perceptions among students and young Arab ethnic women (Karunia \& Wahyuningsih, 2018; Krisnatuti \& Oktaviani, 2011; Sari \& Sunarti, 2013). Meanwhile, this study aimed to explore the key factors that may influence marital readiness, including age, involvement in family life preparation programs, knowledge of family life, and emotional intelligence.

\section{Method}

\section{Research Design}

This quantitative research uses an explanatory design, a research method that intends to explain the variables studied and the influence between one variable and other variables (Sugiyono, 2017). Data collection was carried out during lecture time. The questionnaire was administered by the first author and filled out by all students in each class. Completion of the questionnaire took approximately 30-45 minutes.

\section{Respondent}

One hundred and twenty university students in Jakarta Special Province participated in this study. Participants were selected using the purposive sampling method, with the criterion: age ranging from 18 to 22 years, and single. The average participant's age is 19.42 years. Meanwhile, more than half were female $(68.3 \%)$, and the remaining were male participants $(31.7 \%)$.

\section{Instrument}

Primary data was collected through a questionnaire consists of a demographic data questionnaire and instruments on family life knowledge, emotional intelligence, and marital readiness. The demographic questionnaire was used to collect data on the age of participants and the involvement of family life preparation through PIK-M.

The family life knowledge instrument was developed based on Yatim (2015). This instrument is used to measure student knowledge, including emerging adulthood development, reproductive health, preparation for family life, family life communication, and life skills. This instrument consists of 21 items with four answer choices using the Guttman scale. Therefore, the correct answer score is valued 1, and the wrong answer is valued 0 . Item discrimination index ranged from .459 to .574 , with reliability $\alpha=.669$.

The emotional intelligence was collected with an inventory developed by Latifah (2009) based on emotional intelligence theory (Goleman, 1999). This instrument consists of 48 items with two dimensions: the intrapersonal dimension, which includes self-awareness, self-regulation, self-motivation, and interpersonal dimension, including empathy and social skills. This instrument used a Likert scale with four choices (1) very inappropriate, (2) not appropriate, (3) appropriate, and (4) very suitable. Item discrimination index ranged from .398 to .578 , with reliability $\alpha=.855$. 
Marital readiness was measured using the Family Planning questionnaire based on the theory developed by Ghalili, et al. (2012). Marital readiness measures ten dimensions: age readiness, financial readiness, physical readiness, mental readiness, moral readiness, emotional readiness, social readiness, interpersonal readiness, married life skills, and intellectual readiness. This instrument consists of 48 items with four choices Likert scale (1) very inappropriate, (2) not appropriate, (3) appropriate, and (4) very suitable. Item discrimination index ranged from .460 to .740 , with reliability $\alpha=.898$.

\section{Data Analysis}

Data analysis was performed using PLS-SEM analysis to analyze the effect of age, participation in family life preparation program (PIK-M), family life knowledge, and emotional intelligence on marital readiness. PLS-SEM consists of two models, the measurement model (representing how measured variables represent the constructs) and the structural model (showing how constructs are associated with each other). In PLSSEM, the measurement model is often referred to as the outer model, and the structural model is termed the inner model (Hair, Sarstedt, Hopkins, \& Kuppelwieser, 2014). Test the outer model divided into three: convergent validity, discriminant validity, and composite reliability. Testing the measurement model through the loading factor determines the validity of the indicator by looking at the indicators' value convergent validity. Each indicator in the model must meet outer loading>.7, average variance extracted (AVE) >.5 and a construct said to be reliable if the composite reliability value is above .60. Then on inner model test is done by using the R-Square test and the significance of $\mathrm{T}$ statistics.

\section{Results}

The PLS SEM measurement model results indicate three marital readiness items with an outer loading of less than .5. These items need to be removed from the measurement model. The outer loading value $=.5$ can still be tolerated to be included in a still under development model, and below the value of .5 can be removed from the analysis (Sarwono, 2016). Table 1 shows the AVE value for the emotional intelligence variable is .729, while the marital readiness variable has a value of AVE=.674. The AVE value for the indicator measuring constructs can be expressed as having a value of good discriminant validity. Based on Table 1, it can be explained that from the provisions of composite reliability, it can be stated that the construct researched meets the criteria of composite reliability. This result indicates that the whole composite variables have adequate internal consistency within measure the latent variable to use in subsequent analyses.

The structural model analysis results show $R^{2}=.430$, indicating that age, participation in family life preparation program (PIK-M), family life knowledge, and emotional intelligence significantly affect marital readiness. The model explains that $43 \%$ of the key factors affect marital readiness. While the remaining 57\% are influenced by other variables outside of this study. 
Table 1

The Results of Measurement Model and Structural Model

\begin{tabular}{|c|c|c|c|c|c|}
\hline \multirow[b]{2}{*}{ Variable } & \multirow[b]{2}{*}{ Indicator } & \multicolumn{3}{|c|}{ Outer Model } & \multirow{2}{*}{$\begin{array}{c}R- \\
\text { Square } \\
\left(R^{2}\right)\end{array}$} \\
\hline & & $\begin{array}{c}\text { Outer } \\
\text { Loading }\end{array}$ & AVE & $\mathrm{CR}$ & \\
\hline Age & $\mathrm{Ag}$ & 1.000 & 1.000 & 1.000 & \\
\hline Involvement in Family Life Preparation Program & PIK-M & 1.000 & 1.000 & 1.000 & \\
\hline Family Life Knowledge & PKB & 1.000 & 1.000 & 1.000 & \\
\hline \multirow[t]{2}{*}{ Emotional Intelligence } & TRA & .856 & \multirow{2}{*}{.729} & \multirow{2}{*}{.843} & \\
\hline & TER & .852 & & & \\
\hline \multirow[t]{7}{*}{ Marital Readiness } & SR & .808 & \multirow{7}{*}{.674} & \multirow{7}{*}{.935} & \multirow{7}{*}{430} \\
\hline & PR & .682 & & & \\
\hline & MLS & .853 & & & \\
\hline & MER & .864 & & & \\
\hline & IR & .890 & & & \\
\hline & INR & .815 & & & \\
\hline & MOR & .811 & & & \\
\hline
\end{tabular}

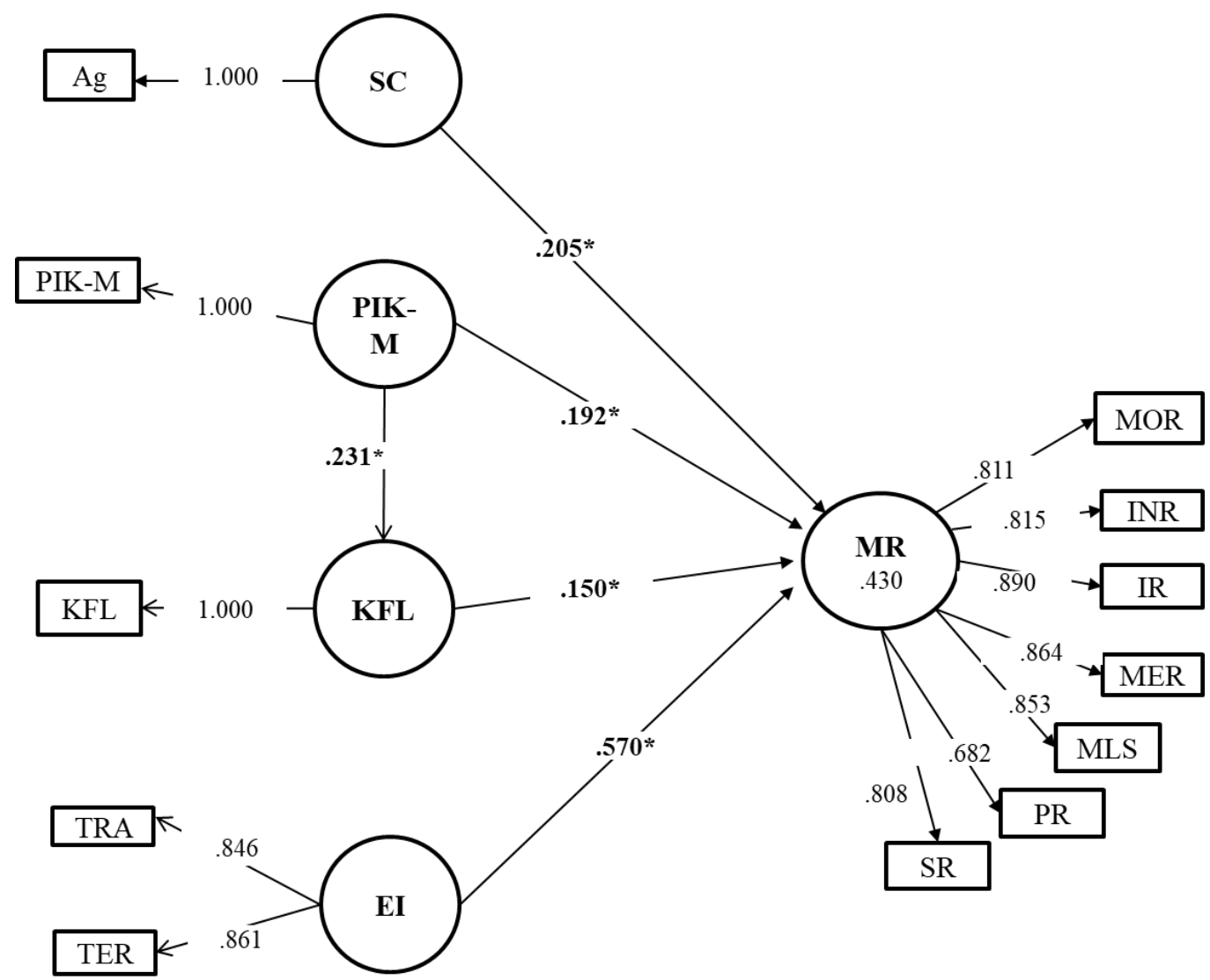

Figure 1. The PLS-SEM analysis model of marital readiness

Figure 1 and Table 2 shows that the four variables positively significantly affect marital readiness. Age has a direct effect on marital readiness $(\beta=.205 ; t>1.96)$. This finding means that the higher age, the higher marital readiness will be. The involvement in the family life preparation program (PIK-M) has a direct effect on marital readiness $(\beta=.192 ; t>1.96)$ and also on family life knowledge $(\beta=.231 ; t>1.96)$. This result indicates that participating in a family life preparation program (PIK-M) will increase 
family life knowledge. Family life knowledge also has a direct effect on marital readiness $(\beta=.150 ; t>1.96)$. This result means that the higher the level of family life knowledge, the higher marital readiness will be. Individuals who understand family life will tend to have better marital readiness. Emotional intelligence through these two dimensions directly influences students' marital readiness $(\beta=.570 ; t>1.96)$. This finding indicates that the higher emotional intelligence, the higher marital readiness will be.

Table 2

The Path Analysis

\begin{tabular}{lr}
\hline \multicolumn{1}{c}{ Path } & $\begin{array}{c}\text { Path } \\
\text { Coefficient }\end{array}$ \\
\hline Age (Ag) $\rightarrow$ Marital readiness (MR) & $.205^{*}$ \\
Involvement in family life preparation program (PIK-M) $\rightarrow$ Marital readiness (MR) & $.192^{*}$ \\
Family life knowledge (KFL) $\rightarrow$ Marital readiness (MR) & $.150^{*}$ \\
Emotional Intelligence (EI) $\rightarrow$ Marital readiness (MR) & $.570^{*}$ \\
Involvement in family life preparation program (PIK-M) $\rightarrow$ Family life knowledge & $.231^{*}$ \\
$($ KFL) & \\
\hline
\end{tabular}

Note: Significant on $t>1.96 ; p<.05$

\section{Discussion}

This study's results found that marital readiness is influenced by age, participation in family life preparation program (PIK-M), family life knowledge, and emotional intelligence. Among all variables, emotional intelligence has the highest impact on marital readiness. The higher the emotional intelligence, the higher the married readiness. Therefore, young adults need to have the emotional intelligence to have marriage readiness. Emotional intelligence is the basis for making decisions to build a family life and face various changes and challenges in marriage. The lack of a partner's ability to manage emotions and a lack of empathy for a partner's feelings are thought to be still the cause of spousal disputes (Ortese \& Tor Anyiin, 2008). Several studies have shown that low self-regulation and empathy can reduce the level of satisfaction in marriage (Asak \& Wilani, 2019; Hajihasani \& Sim, 2018; Sari \& Fauziah, 2017; Wulan \& Chotimah, 2017).

According to Goleman (1999), someone who has social skills will be able to handle emotions well when dealing with other people, interact well, and deliberate to resolve disputes and work together with other people. Social skills are needed in building marriage readiness. According to Erikson (Miller, 2011), the transition from adolescence to adulthood is at the intimacy stage against isolation. At this stage, the individual must build relationships with other people or the opposite sex to form intimacy. This process requires skills to manage one's emotions and relate to others.

Age is related to physical and mental development, including in marriage. Previous studies found the more mature the married age, the better the readiness to marry (Carroll et al., 2009; Larson \& LaMont, 2005; Sari \& Sunarti, 2013). According to Kuperberg (2014), both men and women who marry at a minor age are more likely to divorce because they are not ready to marry. Sari \& Sunarti (2013) shows the different average ages of marriage for men and women (26.15 years and 24.24 years, respectively). Participants in this study had an average age of 19.58 years. Being in young adulthood is the best age for marriage because teenage marriages are more prone to lead to divorce than marriage in adulthood (Santrock, 2014). The more mature the 
marriage age, the better the readiness to marry (Carroll et al., 2009; Larson \& LaMont, 2005; Sari \& Sunarti, 2013).

Participation in the family life preparation program (PIK-M) has a significant impact on family life knowledge and marital readiness. This result is in line with previous research, which shows that participation in education and counseling classes is generally beneficial to increase knowledge and capacity to manage family resources (Arnold, Richardson, \& Cenizal, 2016; Baghersad, Fahami, Beigi, \& Hasanzadeh, 2017). According to Murray \& Murray (2004), pre-marriage preparation counseling can be a resource for young adults to obtain various information and knowledge to improve the relationship's quality after marriage later. Individuals who have participated in prenuptial preparations can be positive and have the resources to deal with various emotional challenges that affect marriage (Duncan, Larson, \& McAllister, 2014). Based on this study's result, the family life preparation program also needs to include emotional intelligence as an essential factor determining marital readiness.

The results of Krisnatuti \& Oktaviani (2011) research indicate that a person will be more ready to marry if he has sufficient knowledge. Knowledge about family life becomes the capital in achieving intellectual readiness to enter married life. Knowledge and skills in managing family resources are needed to fulfill the information needed by the family. Students will have readiness before marriage by participating in a family life preparation program (PIK-M) to increase family life knowledge. If this knowledge is accompanied by high emotional intelligence, students will have the opportunity to have good readiness for marriage. It is necessary to update the relevant family life knowledge material to increase students' understanding of the importance of equipping themselves with the skills needed before marriage.

Marital readiness is built from ten dimensions: age readiness, financial readiness, physical readiness, mental readiness, emotional readiness, moral readiness, social readiness, interpersonal readiness, married life skills, and intellectual readiness (Ghalili et al., 2012). In this research, of the ten dimensions of marital readiness, three dimensions, namely age readiness, financial readiness, and emotional readiness were not meet the minimum factor loading. This result indicates only seven dimensions build the marital readiness construct in this study.

This study has several limitations. First, this study did not involve external variables such as parental involvement or peer support. Future research needs to involve parents as respondents to see how parental marital satisfaction plays a role in young adults' readiness to marry. Second, this study limits the sample based on the student population in Jakarta. Therefore, to apply this study result to a broader population, further research needs to investigate the readiness to marry young adults who live in rural areas with high divorce rates.

\section{Conclusion}

Marital readiness is significantly influenced by age, family preparation program (PIKM), family life knowledge, and emotional intelligence. Among these variables, emotional intelligence was found to have the most significant impact on marital readiness. Among university students with ages ranging from 19 to 22, the higher age, the higher marital readiness will be. The involvement in family preparing programs will increase family life knowledge and increase marital readiness directly and indirectly through family life knowledge. Therefore, to increase marital readiness, the government needs to stimulate emotional intelligence in the family preparing program to enhance marital readiness. 


\section{References}

Arnett, J. J. (2015). Emerging adulthood: The winding road from the late teens through the twenties. Second Edition. Oxford University Press.

Arnold, A. L., Richardson, E. W., \& Cenizal, R. (2016). Ready or not: The influence of readiness on healthy marriage and relationship education training outcomes. Children and Youth Services Review, 63, 67-73. https://doi.org/10.1016/j.childyouth.2016.02.014

Asak, N. L. A. P., \& Wilani, N. M. A. (2019). Peran kecerdasan emosi terhadap kepuasan pernikahan pada remaja yang menikah muda di Bali (The role of emotional intelligence on marriage satisfaction among early married adolescent in Bali). Jurnal Psikologi Udayana, 6(02), 337-346. https://doi.org/10.24843/JPU.2019.v06.i02.p13

Baghersad, Z., Fahami, F., Beigi, M., \& Hasanzadeh, A. (2017). Sexual knowledge and attitude among girls who are getting married based on the information from yas pre-marriage counseling center. Iranian Journal of Nursing and Midwifery Research, 22(3), 255-256.

Carroll, J. S., Badger, S., Willoughby, B. J., Nelson, L. J., Madsen, S. D., \& McNamara-Barry, C. (2009). Ready or not? Criteria for marriage readiness among emerging adults. Journal of Adolescent Research, 24(3), 349-375. https://doi.org/10.1177\%2F0743558409334253

Duncan, S. F., Larson, J. H., \& McAllister, S. (2014). Characteristics of individuals associated with involvement in different types of marriage preparation interventions. Family Relations, 63(5), 680-692. https://doi.org/10.1111/fare.12094

Farnam, F., Pakgohar, M., \& Mir-mohammadali, M. (2011). Effect of pre-marriage counseling on marital satisfaction of Iranian newlywed couples: a randomized controlled trial. Sexuality \& Culture, 15(2), 141-152. https://doi.org/10.1007/s12119-010-9086-6

Fawcett, E. B., Hawkins, A. J., Blanchard, V. L., \& Carroll, J. S. (2010). Do premarital education programs really work? A meta-analytic study. Family Relations, 59(3), 232-239. https://doi.org/10.1111/j.1741-3729.2010.00598.x

Ghalili, Z., Etemadi, O., Ahmadi, S., Fatehizadeh, M., \& Abedi, M. (2012). Marriage readiness criteria among young adults of isfahan: A qualitative study. Interdisciplinary Journal of Contemporary Research in Business, 4(4), 1076-1083.

Goleman, D. (1999). Working with emotional intelligece. Gramedia Pustaka Utama.

Hair Jr. J. F., Sarstedt, M., Hopkins, L., \& Kuppelwieser, V. G. (2014). Partial least squares structural equation modeling (PLS-SEM): An emerging tool in business research. European Business Review, 26(2), 106-121. https://doi.org/10.1108/ebr10-2013-0128

Hajihasani, M., \& Sim, T. (2018). Marital satisfaction among girls with early marriage in Iran: emotional intelligence and religious orientation. International Journal of Adolescence and Youth, 1-10. https://doi.org/10.1080/02673843.2018.1528167

Holman, T. B., \& Li, B. D. (1997). Premarital factors influencing perceived readiness for marriage. Journal of Family Issues, 18(2), 124-144. https://doi.org/10.1177/019251397018002002

Kalsoom, S., \& Kamal, A. (2018). Emotional intelligence and multitasking ability predictors of marital adjustment of working married individuals. FWU Journal of Social Science, 12(2), 60-73. 
Kamel Abbasi, A. R., Tabatabaei, S. M., Aghamohammadiyan Sharbaf, H., \& Karshki, H. (2016). Relationship of attachment styles and emotional intelligence with marital satisfaction. Iranian Journal of Psychiatry and Behavioral Sciences, 10(3). https://doi.org/10.17795/ijpbs-2778

Karunia, N. E., \& Wahyuningsih, S. (2018). Kesiapan menikah perempuan emerging adulthood etnis Arab (Marital readiness among Arabic emerging adulthood women). JPIB: Jurnal Psikologi Islam Dan Budaya, 1(2), 75-84. https://doi.org/10.15575/jpib.vli2.3303

Krisnatuti, D., \& Oktaviani, V. (2011). Persepsi dan kesiapan menikah pada mahasiswa (Perception and marital readiness among university students). Jurnal Ilmu Keluarga Dan Konsumen, 4(1), 30-36. https://doi.org/10.24156/jikk.2011.4.1.30

Kuperberg, A. (2014). Age at coresidence, premarital cohabitation, and marriage dissolution: 1985-2009. Journal of Marriage and Family, 76(2), 352-369. https://doi.org/10.1111/jomf.12092

Kurniawan, L. S. (2019). Emotional intelligence and marital decision. International Journal of Health Sciences, 3(2), 11-20. https://doi.org/10.29332/ijhs.v3n2.287

Larson, J. H., \& LaMont, C. (2005). The relationship of childhood sexual abuse to the marital attitudes and readiness for marriage of single young adult women. Journal of Family Issues, 26(4), 415-430. https://doi.org/10.1177\%2F0192513X04270474

Larson, J. H., \& Thayne, T. R. (1999). Marital attitudes and personal readiness for marriage of young adult children of alcoholics. Alcoholism Treatment Quarterly, 16(4), 59-73. https://doi.org/10.1300/j020v16n04_06

Latifah, M. (2009). Instrumen pengukuran kecerdasan emosional remaja (Instrument for measuring adolescent emotional intelligence). IPB University.

Meiandayati, R., Nirmala, S. A., Didah, D., \& Susanti, A. I. (2015). Kejadian pernikahan usia dini berdasarkan karakteristik dan sosial budaya di Desa Cipacing Kecamatan Jatinangor Kabupaten Sumedang tahun 2014 (The incidence of early marriage based on socio-cultural characteristic in Cipacing Village Jatinangor Subdistrict, Sumedang District in 2014). Jurnal Sistem Kesehatan, 1(2), 76-83. https://doi.org/10.24198/jsk.v1i2.18129

Miller, P. H. (2011). Theories of developmental psychology. Fifth Edition. Worth Publishers.

Murray, C. E., \& Murray Jr. T. L. (2004). Solution-focused premarital counseling: Helping couples build a vision for their marriage. Journal of Marital and Family Therapy, 30(3), 349-358. https://doi.org/10.1111/j.1752-0606.2004.tb01245.x

Ortese, P. T., \& Tor-Anyiin, S. A. (2008). Effects of emotional intelligence on marital adjustment of couples in Nigeria. Ife Psychologia, 16(2), 101-112. https://doi.org/10.4314/ifep.v16i2.23804

Papalia, D. E., Olds, S. W., \& Feldman, R. D. (2009). Human development. McGrawHill.

Santrock, J. W. (2014). Adolescence. Fifteenth Edition. McGraw-Hill Education.

Sari, A. N., \& Fauziah, N. (2017). Hubungan antara empati dengan kepuasan pernikahan pada suami yang memiliki istri bekerja (The relayionship between empathy and marriage satisfaction among husband with working wife). Jurnal Empati, 5(4), 667-672.

Sari, F., \& Sunarti, E. (2013). Kesiapan menikah pada dewasa muda dan pengaruhnya terhadap usia menikah (Marital readines among young adult and the impact on marital age). Jurnal Ilmu Keluarga \& Konsumen, 6(3), 143-153. https://dx.doi.org/10.24156/jikk.2013.6.3.143 
Sari, Y., Khasanah, A. N., \& Sartika, S. (2016). Studi mengenai kesiapan menikah pada muslim dewasa muda (Study on marital readiness among Moslem young adult). Prosiding SNaPP: Kesehatan (Kedokteran, Kebidanan, Keperawatan, Farmasi, Psikologi), 2(1), 193-204.

Sarwono, J. (2016). Membuat Skripsi, Tesis dan Disertasi dengan Partial Least Square SEM (PLS - SEM) (Undergraduate thesis, thesis and desertation with Partial Least Square SEM (PLS - SEM)). Penerbit Andi.

Setiawati, E. R., \& Marnelly, T. R. (2017). Pengaruh pernikahan dini terhadap keharmonisan pasangan suami dan istri di Desa Bagan Bhakti Kecamatan Balai Jaya Kabupaten Rokan Hilir (The effect of early marriage on harmony between husband and wife in Bagan Bhakti Village Balai Jaya Sub-district Rokan Hilir District). Jurnal Online Fakultas Ilmu Sosial Dan Ilmu Politik Universitas Riau, 4(1), 1-13.

Statistic Indonesia. (2020). Statistic Indonesia 2020. Badan Pusat Statistik.

Sugiyono. (2017). Metode penelitian kuantitatif, kualitatif, dan R\&D (Quantitativa, qualitative research methods and $R \& D)$. Alfabeta, $\mathrm{CV}$.

Sunarti, E., Simanjuntak, M., Rahmatin, I., \& Dianeswari, R. (2012). Kesiapan menikah dan pemenuhan tugas keluarga pada keluarga dengan anak usia prasekolah (Marriage readiness and fulfilment of family duties among family with preschool age children). Jurnal Ilmu Keluarga \& Konsumen, 5(2), 110-119. https://doi.org/10.24156/jikk.2012.5.2.110

Tsania, N., Sunarti, E., \& Krisnatuti, D. (2015). Karakteristik keluarga, kesiapan menikah istri, dan perkembangan anak usia 3-5 tahun (Family characteristic, wife marital readiness and the development of children age 3-5 years). Jurnal Ilmu Keluarga \& Konsumen, 8(1), 28-37. https://dx.doi.org/10.24156/jikk.2015.8.1.28

Willoughby, B. J., Olson, C. D., Carroll, J. S., Nelson, L. J., \& Miller, R. B. (2012). Sooner or later? The marital horizons of parents and their emerging adult children. Journal of Social and Personal Relationships, 29(7), 967-981. https://doi.org/10.1177/0265407512443637

Wulan, D. K., \& Chotimah, K. (2017). Peran regulasi emosi dalam kepuasan pernikahan pada pasangan suami istri usia dewasa awal (The role of emtion regulation on marriage satisfaction among early adulthood husband and wife). Ecopsy, 4(1), 5863.

Yatim, D. I. (2015). Mempersiapkan generasi remaja berencana (Preparing generation of youth planning). BKKBN. 